\title{
Hydrological variations in central China over the past millennium and their links to the tropical Pacific and North Atlantic oceans
}

\author{
Fucai Duan $^{1}$, Zhenqiu Zhang ${ }^{2,3}$, Yi Wang ${ }^{4,5}$, Jianshun Chen ${ }^{1}$, Zebo Liao ${ }^{3}$, Shitao Chen ${ }^{3}$, Qingfeng Shao ${ }^{3}$, and \\ Kan Zhao ${ }^{3}$ \\ ${ }^{1}$ College of Geography and Environmental Sciences, Zhejiang Normal University, Jinhua 321004, China \\ ${ }^{2}$ School of Life Sciences, Nanjing Normal University, Nanjing 210023, China \\ ${ }^{3}$ College of Geography Science, Nanjing Normal University, Nanjing 210023, China \\ ${ }^{4}$ Department of Geography and School of Global Studies, University of Sussex, Falmer, Brighton BN1 9QJ, UK \\ ${ }^{5}$ Department of Earth System Science, Institute for Global Change Studies, Tsinghua University, Beijing 100084, China
}

Correspondence: Fucai Duan (fcduan@foxmail.com), Zhenqiu Zhang (zhangzhenqiu163@163.com)

and Yi Wang (yi.wang@sussex.ac.uk)

Received: 19 July 2019 - Discussion started: 12 August 2019

Revised: 16 January 2020 - Accepted: 5 February 2020 - Published: 10 March 2020

\begin{abstract}
Variations of precipitation, also called the Meiyu rain, in the East Asian summer monsoon (EASM) domain during the last millennium could help enlighten the hydrological response to future global warming. Here we present a precisely dated and highly resolved stalagmite $\delta^{18} \mathrm{O}$ record from the Yongxing Cave, central China. Our new record, combined with a previously published one from the same cave, indicates that the Meiyu rain has changed dramatically in association with the global temperature change. In particular, our record shows that the Meiyu rain was weakened during the Medieval Climate Anomaly (MCA) but intensified during the Little Ice Age (LIA). During the Current Warm Period (CWP), our record indicates a similar weakening of the Meiyu rain. Furthermore, during the MCA and CWP, our records show that the atmospheric precipitation is similarly wet in northern China and similarly dry in central China, but relatively wet during the CWP in southern China. This spatial discrepancy indicates a complicated localized response of the regional precipitation to the anthropogenic forcing. The weakened (intensified) Meiyu rain during the MCA (LIA) matches well with the warm (cold) phases of Northern Hemisphere surface air temperature. This Meiyu rain pattern also corresponds well to the climatic conditions over the tropical Indo-Pacific warm pool. On the other hand, our record shows a strong association with the North Atlantic climate as well. The reduced (increased) Meiyu rain correlates well with positive (negative) phases of the North Atlantic Oscillation. In
\end{abstract}

addition, our record links well to the strong (weak) Atlantic meridional overturning circulation during the MCA (LIA) period. All abovementioned localized correspondences and remote teleconnections on decadal to centennial timescales indicate that the Meiyu rain was coupled closely with oceanic processes in the tropical Pacific and North Atlantic oceans during the MCA and LIA.

\section{Introduction}

The last millennium was climatically characterized by the Medieval Climate Anomaly (MCA; 800-1350 CE), the Little Ice Age (LIA; 1350-1850 CE), and the Current Warm Period (CWP; 1850 CE to present) (Lamb, 2002; Mann et al., 2009). These three episodes attract broad attention within the scientific and policy-making communities because they contain critical information to distinguish between natural and anthropogenic climate variability. Origins of the MCA and LIA are attributed to the radiative forcing associated with solar activities and volcanic eruptions, yet the CWP is considered to be a result of increasing anthropogenic greenhouse gases (Bradley and Jonest, 1993; Hegerl et al., 2007; Lamoureux et al., 2001; Sigl et al., 2014). In particular, the CWP is much warmer than the MCA (PAGES 2k Consortium, 2013). In association with the global temperature change, East Asian summer monsoon (EASM) precipi- 
tation has changed significantly (Paulsen et al., 2003; Zhang et al., 2008; Tan et al., 2009, 2011a, 2015). Many studies have indicated that the monsoonal climate of China has generally recorded a wetter MCA and drier LIA in the north but shows reverse conditions in the south (Tan et al., 2009, 2018; Chen et al., 2015). However, it is unclear about the hydrological variation during the MCA and LIA over central China. Moreover, less is known about the relative intensity of precipitation between the CWP and MCA, two recent warm periods. An examination of the relative precipitation intensity is the key to evaluating the hydrological responses under anthropogenic warming.

To better understand hydrological responses to anthropogenic warming, it is necessary to appreciate the natural forcing of the hydrological cycle during the MCA and LIA periods before greenhouse gas emissions. The hydroclimate in the EASM domain is strongly influenced by the tropical Pacific and North Atlantic oceans (Wang et al., 2005; Zhang et al., 2018a; Cheung et al., 2018). The tropical Pacific Ocean feeds the warm and moist air directly into the EASM domain and therefore exerts a strong influence (Karami et al., 2015). Several studies have indicated that the hydrological condition in the EASM domain was affected by alternations of La Niña-like and El Niño-like conditions in the tropical Pacific during the last millennium (e.g., Chen et al., 2015; Zhao et al., 2016; Zhang et al., 2018a). However, these studies did not reach an agreement on how the tropical Pacific affects hydrological change in the EASM domain. To precisely understand the spatiotemporal evolution of the hydrological cycle, we need to know exactly which changes in the hydrological cycle are linked to which modes of the Pacific atmosphere-ocean circulation during the MCA and LIA in central China. On the other hand, the North Atlantic signal can be transmitted to other parts of the world through the Atlantic meridional overturning circulation (AMOC; Bond et al., 2001). Marine sedimentary records have suggested that a strong (weak) AMOC over the warm Greenland interstadials (stadials) correlated tightly with intervals of enhanced (reduced) EASM during the last glaciation (Wang et al., 2001a; Jiang et al., 2016). Similarly, weak EASM episodes occurred in association with ice-rafted events in the North Atlantic, which is capable of weakening the AMOC during the Holocene (Wang et al., 2005; Zhao et al., 2016; Zhang et al., 2018b). This covariation implies a persistent influence of the AMOC on EASM. However, available empirical data are still too rare to explore the potential link between the AMOC and regional precipitation (e.g., EASM) during the MCA and LIA intervals.

Here we present a new precisely dated and highly resolved stalagmite record from Yongxing Cave, central China. This record, together with recently published records from the same cave (W. Zhang et al., 2019), advances our understanding of the hydrological cycle in East Asia during the last millennium.

\section{Materials and methods}

Two stalagmites (YX262 and YX275) are used in this study, both from Yongxing Cave $\left(31^{\circ} 35^{\prime} \mathrm{N}, 111^{\circ} 14^{\prime} \mathrm{E}\right.$; elevation 800 ma.m.s.l.; see Fig. 1), central China. The previously published stalagmite YX275 has revealed detailed variability in the EASM since the LIA (W. Zhang et al., 2019). The new candle-like stalagmite YX262 is $159 \mathrm{~mm}$ long and $55 \mathrm{~mm}$ wide. It is composed of white opaque to brown transparent calcite (see Fig. 2). The Yongxing Cave is located between the Chinese Loess Plateau and the Yangtze River. Average annual rainfall is about $1000 \mathrm{~mm}$ at the site of the cave. Atmospheric temperature is about $14.3^{\circ} \mathrm{C}$ and relative humidity is close to $100 \%$ inside the cave. The cave site is climatically influenced by the East Asian monsoon, featured by a wet and warm summer and a dry and cold winter.

Stalagmite YX262 was first halved and then polished for the purpose of the subsequent sampling. For stable isotope analyses, powdered subsamples, weighing about 50 $100 \mu \mathrm{g}$, were drilled on the polished surface along the central growth axis of the stalagmite. A total of 159 subsamples were obtained at $1 \mathrm{~mm}$ increments. The $\delta^{18} \mathrm{O}$ measurements were performed on a Finnigan MAT 253 mass spectrometer at Nanjing Normal University. Results are reported as per mil $(\% o)$ against the standard Vienna Pee Dee Belemnite (VPDB). The precision of $\delta^{18} \mathrm{O}$ is $0.06 \%$ at the $1 \sigma$ level. For U-Th dates, six powdered subsamples, about $100 \mathrm{mg}$ each, were drilled along the central growth layer. Procedures for the chemical separation and purification of uranium and thorium were described in Shao et al. (2017). U and Th isotope measurements were performed on a Neptune multi-collector inductively coupled plasma mass spectrometer (MC-ICP-MS) at Nanjing Normal University. All the dates are in stratigraphic order with an uncertainty of less than $3 \%$ of the actual dates (see Table 1).

\section{Results}

\subsection{Chronology}

The six U-Th dates and corresponding isotopic ratios are shown in Table 1. Adequate uranium concentrations (0.5$0.7 \mathrm{ppm}$ ) and low initial thorium contents (200-700 ppt, with the exception of $1440 \mathrm{ppt}$ ) produced precise dates with small age uncertainty (6-20 years). The chronology for the stalagmite was established by the StalAge algorithm (Scholz and Hoffmann, 2011). The age model shows that the stalagmite YX262 was deposited from 1027 to 1639 CE (see Fig. 2). The age-depth plot indicates that the growth rate of the stalagmite is stable, reaching $0.26 \mathrm{~mm} \mathrm{yr}^{-1}$. The high and stable growth rate suggests that the stalagmite grew continuously without a significant hiatus. Visual inspections confirm the continuity of the stalagmite growth. The temporal resolution is 3.8 years, allowing for a detailed characterization of the 


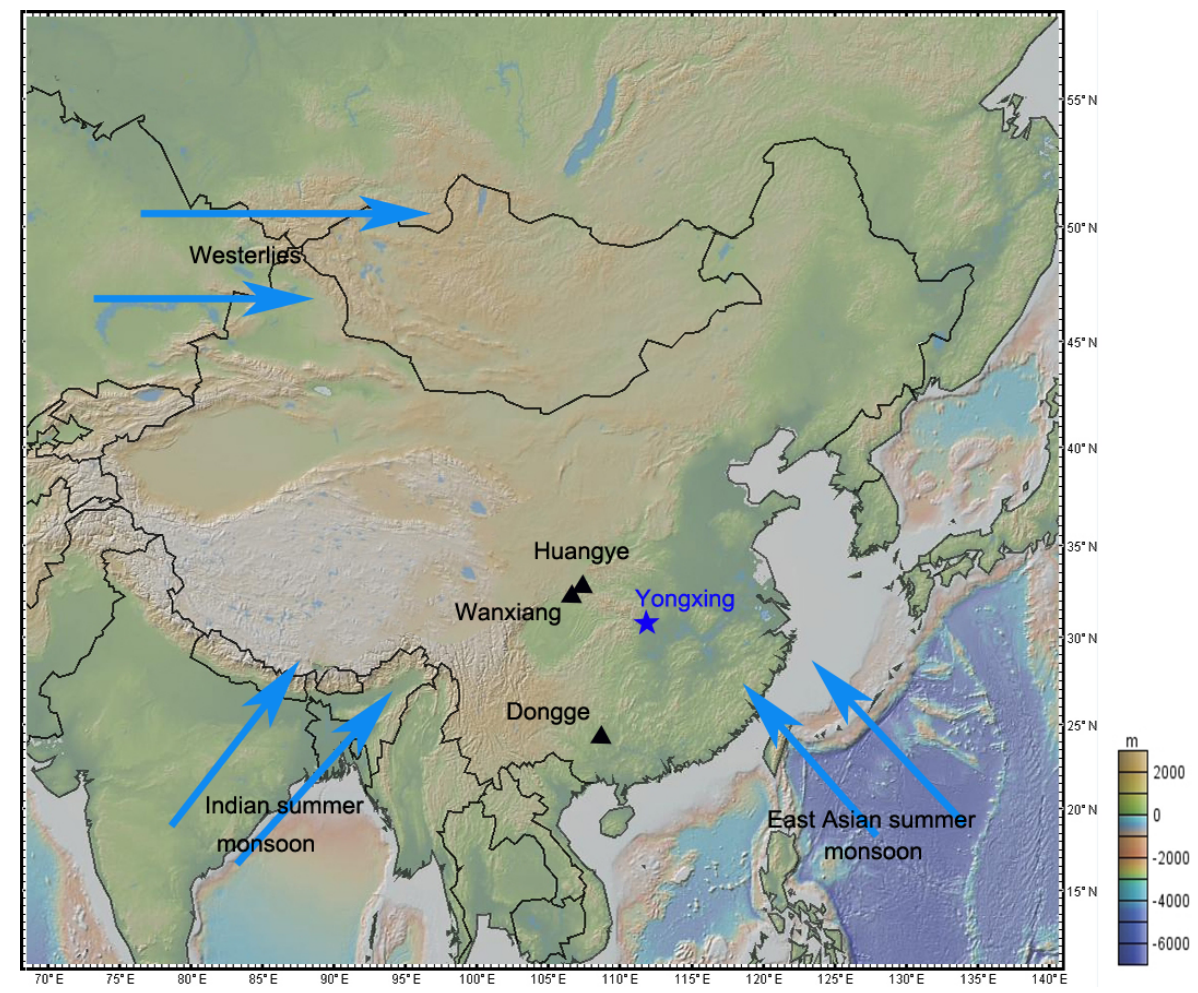

Figure 1. A schematic climate setup of East Asian monsoon systems and our study site. This figure was made with GeoMapApp (http: //www.geomapapp.org, last access: 12 January 2020). The blue star and black triangles represent Yongxing Cave in central China and other caves in the monsoonal region, respectively.

Table 1. U-series dating results of stalagmite YX262 from Yongxing Cave.

\begin{tabular}{lrrrrrrr}
\hline $\begin{array}{l}\text { Sample } \\
\text { depth }(\mathrm{mm})\end{array}$ & $\begin{array}{r}{ }^{238} \mathrm{U} \\
(\mathrm{ppb})\end{array}$ & $\begin{array}{r}{ }^{232} \mathrm{Th} \\
(\mathrm{ppt})\end{array}$ & $\begin{array}{r}\delta^{234} \mathrm{U} \\
\text { (measured) }\end{array}$ & $\begin{array}{r}{ }^{230} \mathrm{Th} /{ }^{238} \mathrm{U} \\
\text { (activity) }\end{array}$ & $\begin{array}{r}{ }^{230} \mathrm{Th} \text { Age (a) } \\
\text { (uncorrected) }\end{array}$ & $\begin{array}{r}\delta^{234} \mathrm{U}_{\text {initial }} \\
\text { (corrected) }\end{array}$ & $\begin{array}{r}{ }^{230} \mathrm{Th} \text { Age }(\mathrm{a}) \\
(\text { corrected) }\end{array}$ \\
\hline $\mathrm{YX} 262-5$ & $546.0 \pm 0.5$ & $307.9 \pm 0.6$ & $607.5 \pm 1.0$ & $0.006230157 \pm 0.00014$ & $423.5 \pm 9.4$ & $608.2 \pm 1.0$ & $413.1 \pm 10.8$ \\
$\mathrm{YX} 262-25$ & $595.5 \pm 0.3$ & $280.5 \pm 0.6$ & $790.6 \pm 1.9$ & $0.00788248 \pm 0.00008$ & $481.0 \pm 5.1$ & $791.7 \pm 1.9$ & $473.1 \pm 6.3$ \\
$\mathrm{YX} 262-48$ & $506.3 \pm 0.3$ & $281.6 \pm 0.5$ & $762.1 \pm 1.9$ & $0.009468079 \pm 0.00010$ & $587.3 \pm 6.4$ & $763.4 \pm 1.9$ & $577.9 \pm 8.0$ \\
YX262-75 & $517.7 \pm 0.3$ & $724.3 \pm 0.1$ & $680.5 \pm 2.1$ & $0.010930422 \pm 0.00010$ & $711.3 \pm 6.4$ & $681.8 \pm 2.1$ & $686.3 \pm 13.9$ \\
YX262-95 & $651.8 \pm 0.3$ & $1448.0 \pm 0.3$ & $806.5 \pm 2.0$ & $0.013146471 \pm 0.00010$ & $796.0 \pm 6.3$ & $808.3 \pm 2.0$ & $759.4 \pm 19.1$ \\
YX262-116 & $583.4 \pm 0.8$ & $283.0 \pm 0.4$ & $956.6 \pm 1.0$ & $0.014987259 \pm 0.00012$ & $838.0 \pm 6.6$ & $958.9 \pm 1.0$ & $830.8 \pm 7.5$ \\
\hline
\end{tabular}

Decay constant values are $\lambda_{234}=2.82206 \times 10^{-6} \mathrm{a}^{-1}, \lambda_{238}=1.55125 \times 10^{-10} \mathrm{a}^{-1}, \lambda_{230}=9.1705 \times 10^{-16} \mathrm{a}^{-1}$, and $\delta^{234} \mathrm{U}=\left(\left[{ }^{234} \mathrm{U} /{ }^{238} \mathrm{U}\right]_{\text {activity }}-1\right) \times 1000$. The corrected ${ }^{230} \mathrm{Th}$ age calculation, indicated in bold, is based on an assumed initial ${ }^{230} \mathrm{Th} /{ }^{232} \mathrm{Th}$ atomic ratio of $(4 \pm 2) \times 10^{-6}$. All corrected dates are years before $2017 \mathrm{CE}$.

Asian hydroclimate for the first half of the second millennium.

\subsection{Stable isotope}

The $\delta^{18} \mathrm{O}$ record of YX262 displays a pronounced fluctuation during the whole period (see Fig. 3). The $\delta^{18} \mathrm{O}$ values range from $-9.31 \%$ to $-7.88 \%$, averaging $-8.60 \%$. The $\delta^{18} \mathrm{O}$ values decrease gradually from 1027 to $1372 \mathrm{CE}$ and then increase gradually before rapidly increasing to the ${ }^{18} \mathrm{O}$ enriched conditions from $1515 \mathrm{CE}$. The interval with high $\delta^{18} \mathrm{O}$ values is $\sim 100$ years long, which is terminated by a pulse to more negative values at $1626 \mathrm{CE}$. In general, the ${ }^{18} \mathrm{O}$-depleted interval is coeval with the MCA and the ${ }^{18} \mathrm{O}$ enriched interval corresponds to the early LIA (see Fig. 3).

\section{Discussion}

\subsection{The interpretation of our $\delta^{18} \mathrm{O}$}

Stalagmite YX262 was deposited under the condition of isotope equilibrium. Relative to the Hendy tests, replication tests have been considered a more vigorous method to examine isotope equilibrium (Dorale and Liu, 2009). The YX262 


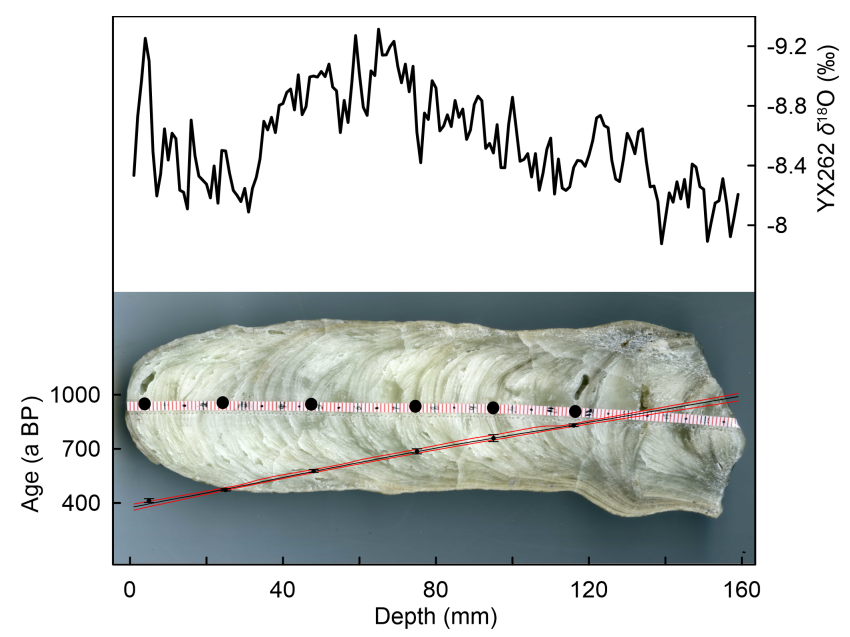

Figure 2. The age versus depth model, image, and $\delta^{18} \mathrm{O}$ record for our stalagmite YX262. The small black dots and vertical error bars indicate ${ }^{230}$ Th dates and the errors of these dates, respectively. The big black dots represent the locations of ${ }^{230} \mathrm{Th}$ dates. The middle green line indicates the model age, and the upper and lower red lines indicate the age at the $95 \%$ confidence level.

$\delta^{18} \mathrm{O}$ record matches another Yongxing Cave record during the overlapping interval (see Fig. 5; W. Zhang et al., 2019), indicating an equilibrium condition for the isotope. A minor difference exists between the two stalagmite $\delta^{18} \mathrm{O}$ records. The YX262 record shows a larger shift toward more negative values than the YX275 record in the early 1600s. Different feeding systems for both the stalagmites probably produce the $\delta^{18} \mathrm{O}$ discrepancy. Longer mixing of meteorological rain within the overlying bedrock may dampen the overall rain $\delta^{18} \mathrm{O}$ amplitude and therefore lead to the calcite $\delta^{18} \mathrm{O}$ offsets (Tan et al., 2019; Carolin et al., 2013). The more negative $\delta^{18} \mathrm{O}$ shift occurred at the beginning of the growth of stalagmite YX262. At the beginning, the mixing of meteorological rain within the overlying bedrock is low, resulting in the lighter $\delta^{18} \mathrm{O}$ values. Overall, the good replication between the two records suggests that the YX262 $\delta^{18} \mathrm{O}$ signal is less influenced by the kinetic fractionation and is primarily of climatic origin. Nevertheless, the climatic significance of the cave $\delta^{18} \mathrm{O}$ record in eastern China remains a longterm scientific debate. For example, the $\delta^{18} \mathrm{O}$ records were considered to reflect changes in moisture sources (the socalled "circulation effect"; Tan, 2014, 2016), moisture pathways (Baker et al., 2015), and a combination of the EASM and winter temperature (Clemens et al., 2010, 2018). Two recent review articles have greatly enlightened our understanding of the stalagmite $\delta^{18} \mathrm{O}$ records in the EASM domain (H. Zhang et al., 2019; Cheng et al., 2019). They have proposed that the cave $\delta^{18} \mathrm{O}$ records reflect large-scale and integrated changes in the Asian summer monsoon intensity on orbital and millennial scales. This interpretation is supported by strong correlations among the cave $\delta^{18} \mathrm{O}$ records

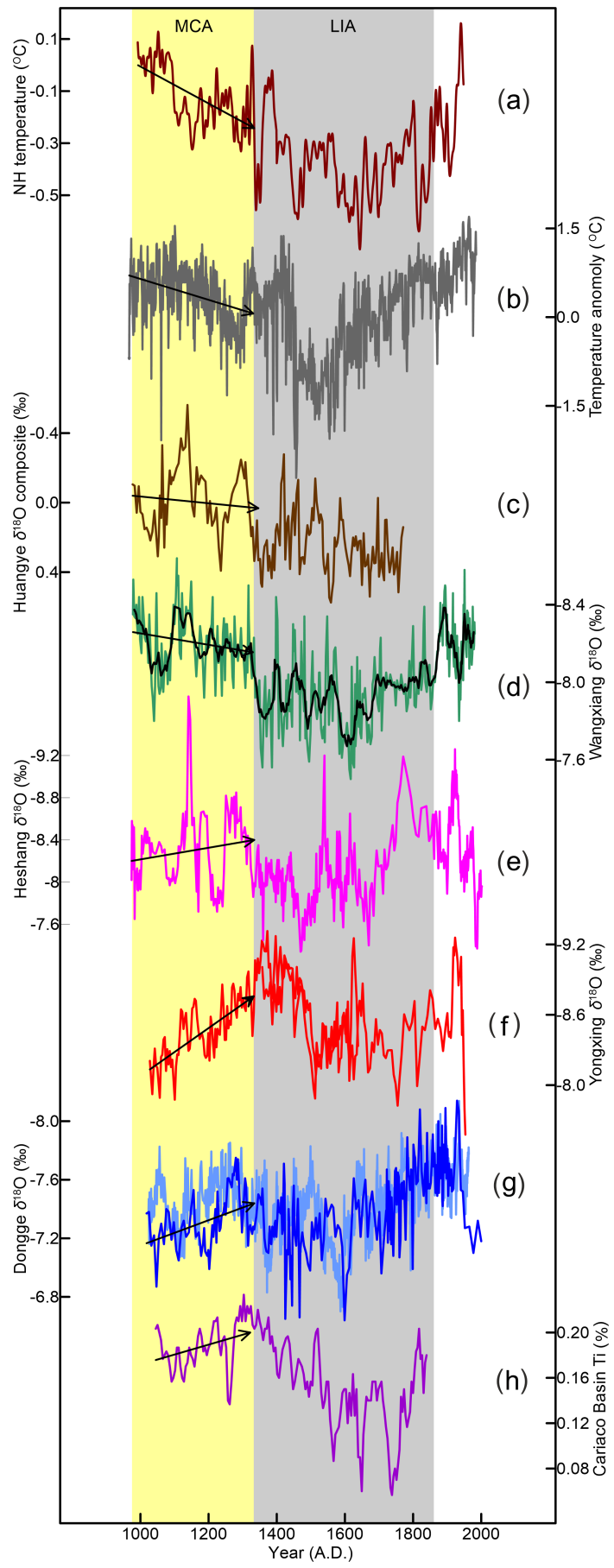

Figure 3. A comparison of the Yongxing $\delta^{18} \mathrm{O}$ time series with other proxy records. (a) Northern Hemisphere reconstructed temperature (Mann et al., 2009); (b) northern China reconstructed temperature (Tan et al., 2003); (c) Huangye Cave $\delta^{18} \mathrm{O}$ composite (Tan et al., 2011b); (d) Wanxiang Cave $\delta^{18} \mathrm{O}$ record (Zhang et al., 2008); (e) Heshang Cave $\delta^{18} \mathrm{O}$ record (Hu et al., 2008); (f) Yongxing Cave record (this study); (g) Dongge Cave record (Wang et al., 2005; Zhao et al., 2015); (h) Cariaco Basin Ti content record (Haug et al., 2001). Light yellow and blue bars indicate the MCA and LIA, respectively. Arrows, constrained by linear fit methods, indicate trends of the climatic variations. 


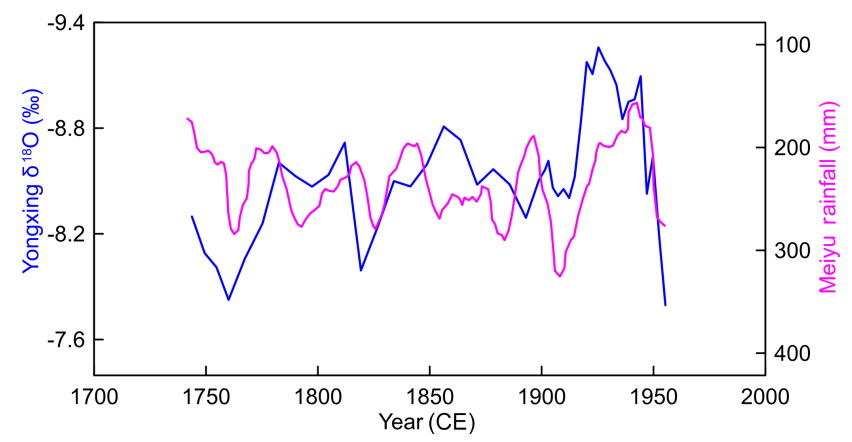

Figure 4. A comparison between the Yongxing $\delta^{18} \mathrm{O}$ record (blue line) and reconstructed Meiyu rain (pink line; 7-year running average; Ge et al., 2008).

across China (e.g., Yuan et al., 2004; Zhao et al., 2010; Cheng et al., 2009, 2016) and correlations with climate conditions in major global climate systems, such as Antarctica, Greenland, and the westerly climate (see Figs. 2 and 3 in Cheng et al., 2019). The stalagmite $\delta^{18} \mathrm{O}$ values reflect changes in the fraction of water vapor precipitated out between tropical oceans and cave locations (H. Zhang et al., 2019; Cheng et al., 2019). A strengthened (weakened) EASM indicates increased (decreased) rainout along the moisture trajectory and therefore lighter (heavier) stalagmite $\delta^{18} \mathrm{O}$ values (H. Zhang et al., 2019; Cheng et al., 2019). However, the interpretation of the stalagmite $\delta^{18} \mathrm{O}$ records remains complex on annual to centennial scales due to a wide range of potential influencing factors, such as summer rainfall, moisture sources, and seasonality of precipitation (H. Zhang et al., 2019; Cheng et al., 2019). At the Dongge Cave location, stalagmite $\delta^{18} \mathrm{O}$ records were interpreted to be associated with monsoon precipitation on the decadal to centennial scale because of its covariation with the local hydrological proxy, annual band thickness (Zhao et al., 2015). Our Yongxing $\delta^{18} \mathrm{O}$ record in central China correlates well with Meiyu rain fluctuations in the middle and lower reaches of the Yangtze River on the decadal to centennial scale (see Fig. 4; Ge et al., 2008). When the stalagmite $\delta^{18} \mathrm{O}$ values are lighter (heavier), the Meiyu rain is weaker (stronger). This relationship is further supported by inverse correlations of stalagmite $\delta^{18} \mathrm{O}$ records with local rainfall variation (trace element ratio and $\delta^{13} \mathrm{C}$ ) in the nearby Haozhu Cave (Zhang et al., 2018c). As suggested in Zhang et al. (2018c) and Cheng et al. (2019), increased (weakened) EASM would lead to a shorter (longer) Meiyu rain stage and thus a decrease (increase) in precipitation in the middle and lower reaches of the Yangtze River. Thus, the Yongxing $\delta^{18} \mathrm{O}$ signal mainly reflects Meiyu rain conditions on decadal to centennial scales, with lower and higher $\delta^{18} \mathrm{O}$ values reflecting decreased and increased rainfall, respectively.

\subsection{The regional characters of the MCA and LIA}

The climate condition during the MCA and LIA has been extensively studied for monsoonal China (e.g., Chen et al., 2015; Xu et al., 2016; Tan et al., 2018). In general, wetter conditions in the north and drier in the south were inferred during the MCA and the opposite during the LIA (e.g., Chen et al., 2015; Tan et al., 2018). The boundary between the north and south of China was estimated to be along the River Huai at $34^{\circ} \mathrm{N}$ (Chen et al., 2015), the modern geographical dividing line between northern and southern China. As an interesting exception, the Dongge Cave records in Guizhou, southwestern China $\left(25^{\circ} 17^{\prime} \mathrm{N}, 108^{\circ} 5^{\prime} \mathrm{E}\right)$, showed a wetter MCA and drier LIA (see Fig. 3; Wang et al., 2005; Zhao et al., 2015). This is consistent with strong spatiotemporal variability of precipitation in the broad EASM region.

Our Yongxing record, slightly south of $34^{\circ} \mathrm{N}$, is further supported by the nearby Heshang $\delta^{18} \mathrm{O}$ record, despite larger chronological offsets between them (see Fig. 3; Hu et al., 2008). Both stalagmite $\delta^{18} \mathrm{O}$ records consistently show a trend toward lighter values over the MCA period and a double valley structure over the LIA period. An extra comparison shows that the Yongxing and Heshang (Hu et al., 2008) $\delta^{18} \mathrm{O}$ records in central China vary broadly in phase with the Dongge record in the south, as well as the Wanxiang (Zhang et al., 2008) and Huangye (Tan et al., 2011b) records in the north. These cave records indicate a drier MCA and wetter LIA in central China, but the opposite in the north and south (see Fig. 3). Again, a minor but important discrepancy exists between these cave records during the MCA. The cave records in the south display an increasing precipitation trend, but those in northern and central China reflect a decreasing trend during the MCA (see Fig. 3 for the trends indicated by the arrows). To explain this discrepancy, we compare all the cave records to changes in temperatures in the Northern Hemisphere (Mann et al., 2009) and northern China (Tan et al., 2003), as well as the meridional displacement of the Intertropical Convergence Zone (ITCZ; Haug et al., 2001). The result indicates that all the cave records collectively exhibit a broad similarity to the variation in temperatures and the displacement of the ITCZ (see Fig. 3). Detailed inspection reveals that the weakening precipitation signal recorded in the northern caves during the MCA is linked to the decreasing temperatures in the Northern Hemisphere and northern China. In contrast, the intensifying signal recorded in the southern cave during the MCA corresponds to the northward displacement of the ITCZ. The comparison indicates that the different climate patterns between the south and north may result from different controlling factors at lower and higher latitudes, respectively. The "north drought" and "south flood" could result from the meridional migration of the Meiyu rain belt (Yu and Zhou, 2007; Zhou et al., 2009; Zhang et al., $2018 \mathrm{c})$. It seems that the cold temperature from the north restrains the northward migration of the Meiyu rain belt related to the movement of the ITCZ during the MCA, leading to 
a hydrological seesaw between northern and central China. It is noted that the enhanced precipitation condition documented in the Dongge records is contradictory to those reported in many other paleoclimate records in the south. For example, a drier MCA and wetter LIA were suggested in an integrated stalagmite $\delta^{18} \mathrm{O}$ record from Sichuan Province (Tan et al., 2018), a pollen-derived rainfall record near the Yongxing Cave site (He et al., 2003), and a lake-based rainfall record in Guangdong Province (Chu et al., 2002). This regional discrepancy can be checked by additional highly resolved and precisely dated records in southern China.

\subsection{The hydrological condition during the MCA compared to the CWP}

A comparison of the relative intensity of precipitation between the MCA and CWP could be useful to evaluate the hydrological response to the current global warming. Many studies have found that the CWP is much warmer than the MCA on global and hemispheric scales (Bradley et al., 2003; Mann et al., 2008, 2009; PAGES 2k Consortium, 2013). With regard to the hydrological response, northern China shows an increased or comparable precipitation maximum during the MCA compared to the CWP (e.g., the Wanxiang and Huangye Cave records in Fig. 3). A similar precipitation minimum is documented in the Yongxing and Heshang records in central China (see Fig. 3). However, two Dongge records in southern China collectively show a slight decrease in precipitation maximum during the MCA compared to the CWP (see Figs. 3, 5). This is indicated by a $0.39 \%$ higher $\delta^{18} \mathrm{O}$ maximum during the MCA than the CWP (see Fig. 5). The increased precipitation during the CWP relative to the MCA is parallel to the global temperature evolution, in particular in the western Pacific Warm Pool region (Chen et al., 2018). This correspondence supports the hypothesis that current global warming intensifies the Asian summer monsoon (Wang et al., 2013). The intensified Asian summer monsoon was suggested due to strong coupling of the climate system related to global warming. Wang et al. (2013) have stated that a mega ENSO (El Niño-Southern Oscillation) condition could trigger a stronger EASM in the CWP through the intensified Hadley and Walker circulations. On the other hand, southern China is partially influenced by the Indian Ocean, which also brings moisture to the area of our study (An et al., 2011). We suggest that the small discrepancy between the Yongxing and Dongge records could be due to the different localized effects in southern China, as Dongge Cave is much closer to the Indian Ocean than Yongxing Cave.

Different scenarios exist in the South China Sea regarding the hydrologic variation between the MCA and CWP. The South China Sea is climatically influenced by the EASM and tropical Pacific climate. The lacustrine and coralline records collectively indicate a comparative climate condition between the MCA and CWP (e.g., Yan et al., 2011b; Deng et al., 2017). The MCA and CWP are considered to be drier

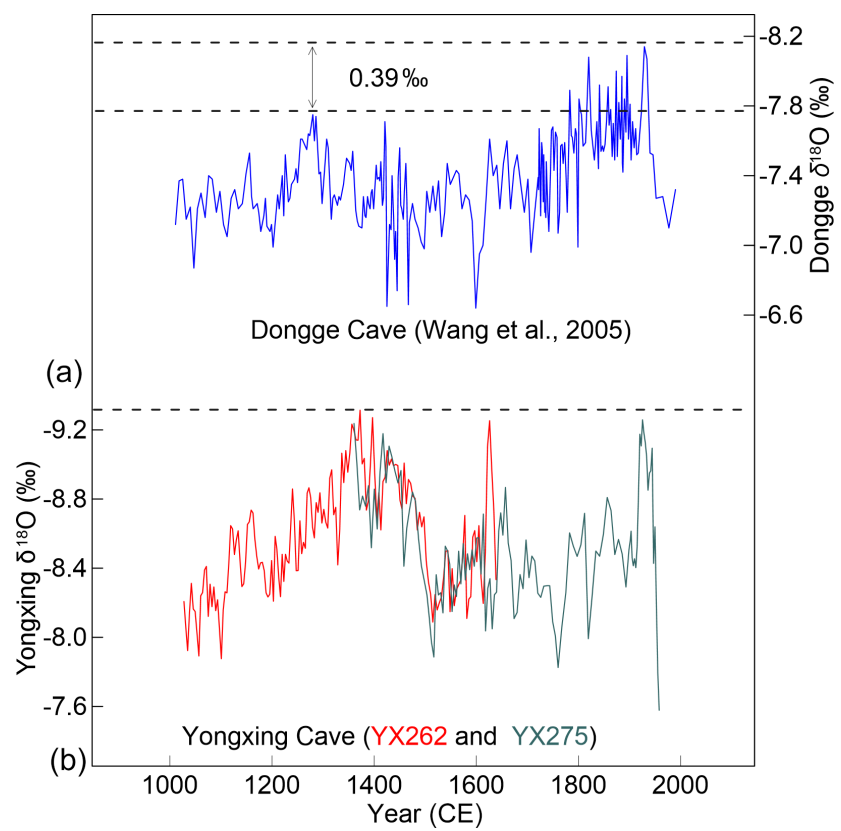

Figure 5. The relative intensity of Meiyu rain during the MCA compared to the CWP. (a) The Dongge Cave record (blue curve; Wang et al., 2005); (b) the Yongxing Cave YX262 (red curve) and YX275 (green curve; W. Zhang et al., 2019) records. On average, the Dongge Cave record shows a $0.39 \%$ o lower $\delta^{18} \mathrm{O}$ value during the CWP than the MCA. However, the Yongxing record shows a comparable value between the CWP and MCA.

than the LIA in the South China Sea. Yan et al. (2011b) highlighted the fact that a decrease and eastward shift of the Pacific Walker circulation were primarily responsible for the drier climate condition during the MCA and CWP. However, changes in the Walker circulation (Yan et al., 2011b) are in contrast to other estimations (Wang et al., 2013; Cobb et al., 2003), which suggested a strong and westward Pacific Walker circulation during the warm periods. Due to the contradiction regarding the Pacific Walker circulation changes, the trigger for the intensified Asian monsoon during the CWP needs further verification. Therefore, continued studies are needed on the links between the EASM and the Pacific climate.

\subsection{The link to the equatorial tropical Pacific Ocean}

The ITCZ and El Niño-Southern Oscillation (ENSO) exerted profound influences on the precipitation in East Asia during the last millennium (Wang et al., 2013). As shown in Fig. 6, our calcite record shows a great similarity to temperature and hydrology reconstructions over the tropical IndoPacific warm pool (IPWP). High-resolution sediment (Oppo et al., 2009) and speleothem (Griffiths et al., 2016) records over the IPWP collectively suggest warm sea surface temperatures and increased rainfall during the MCA and CWP, 


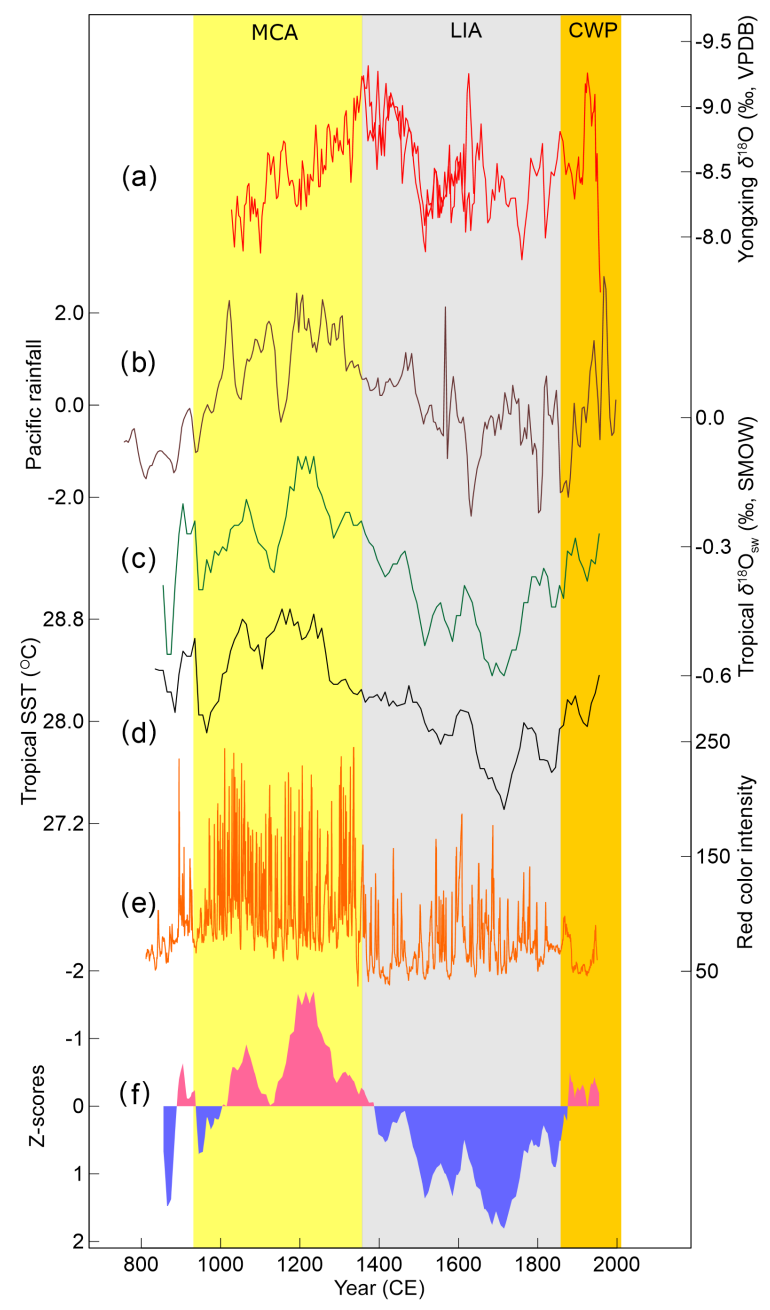

Figure 6. A comparison between Meiyu rain and Pacific climate. (a) Yongxing Cave record (this study); (b) tropical Pacific rainfall record (Oppo et al., 2009); (c) tropical Pacific $\delta^{18} \mathrm{O}$ record (Oppo et al., 2009); (d) tropical Pacific sea surface temperature (Oppo et al., 2009); (e) red color intensity in southern Ecuador (Moy et al., 2002); (f) hydrological reconstruction of ENSO from the tropical Pacific (Yan et al., 2011a). Yellow, grey, and orange bands represent the MCA, LIA, and CWP, respectively.

as well as reversed conditions during the LIA (Fig. 6). The rainfall over the IPWP is linked to the Meiyu rain.

This correlation probably stems from modulations of the ITCZ's latitudinal migration on the EASM and thus Meiyu during the last millennium (Zhao et al., 2015; Xu et al., 2016; Griffiths et al., 2016). In addition, the temperature change over the IPWP can indirectly influence the Meiyu rain via the expansion and contraction of the ITCZ (Yan et al., 2015; Chen et al., 2018). A northward migration or expansion of the ITCZ over the Indo-Pacific warm pool would strengthen the EASM and shorten the Meiyu stage. Conversely, a southward migration or contraction of the ITCZ would weaken the EASM and prolong the Meiyu stage (Zhang et al., 2018c).
The warm MCA and cold LIA conditions do not necessarily signify a La Niña-like condition during the MCA and an El Niño-like condition during the LIA over the IPWP. Conversely, rainfall-based ENSO reconstructions showed El Niño- and La Niña-like conditions during the MCA and LIA, respectively (Moy et al., 2002; Yan et al., 2011a; Fig. 6e, f). The sediment-derived ENSO variation in Ecuador (Moy et al., 2002) and the composite ENSO reconstruction across the tropical Pacific (Yan et al., 2011a) showed a great similarity among the ENSO signals and the timing of switches between the ENSO cold and warm phases. These ENSO reconstructions resemble the Yongxing records (see Fig. 6; $R_{Y X \text { record composite ENSO }}=0.18, P<0.05, N=186$ ). For example, the El Niño- and La Niña-like conditions during the MCA and LIA are in parallel with the decreased and increased Meiyu rain from the Yongxing Cave, respectively. In particular, the switch of the ENSO phases from the MCA to LIA coincides with the Meiyu rain minimum during the MCA (see Fig. 6). These strong correlations indicate a dynamical link between the Meiyu rain and ENSO modes. In the summer after the El Niño evolves to maturity, an abnormally blocked anticyclone takes place in northeast Asia. At the same time, the subtropical high in the western North $\mathrm{Pa}$ cific extends westward abnormally. This abnormal circulation pattern strengthens the EASM in subtropical East Asia (Wang et al., 2001b). The strengthened EASM leads to more rain over northern China and less over central China (Zhang et al., 2018c). Despite the potential Meiyu-ENSO link, the ENSO reconstructions still need further verification due to their different variations. A recent temperature record in eastern equatorial Pacific (Rustic et al., 2015) supports the rainfall-based ENSO reconstruction (Moy et al., 2002; Yan et al., 2011a), with the El Niño- and La Niña-like mode during the MCA and LIA, respectively. This record challenges the paradigm of the La Niña-like pattern during the MCA followed by the El Niño-like pattern during the LIA (Cobb et al., 2003). However, the study of Rustic et al. (2015) showed that the strongest El Niño-like situation occurred in the late MCA to early LIA transition, instead of the peak MCA.

\subsection{The link to the North Atlantic climate}

Our Yongxing record shows a good correlation with the North Atlantic climate. As illustrated in Fig. 7, the decreased (increased) Meiyu rain during the MCA (LIA) coincides with a persistent positive (neutral to slightly negative) North Atlantic Oscillation index (NAO; Trouet et al., 2009; see Fig. 7c; $R=-0.19 ; P<0.05 ; N=182$ ). In addition, these Meiyu rain variations resemble changes in the Atlantic meridional overturning circulation (AMOC), measured by the drift ice index (see Fig. 7d; Bond et al., 2001) and mean grain size of sortable silt (see Fig. 7e; Thornalley et al., 2018; $R=0.39 ; P<0.01 ; N=186$ ) in the North Atlantic. The decreased Meiyu rain corresponds to the strong AMOC during the MCA and the increased Meiyu rain to the 


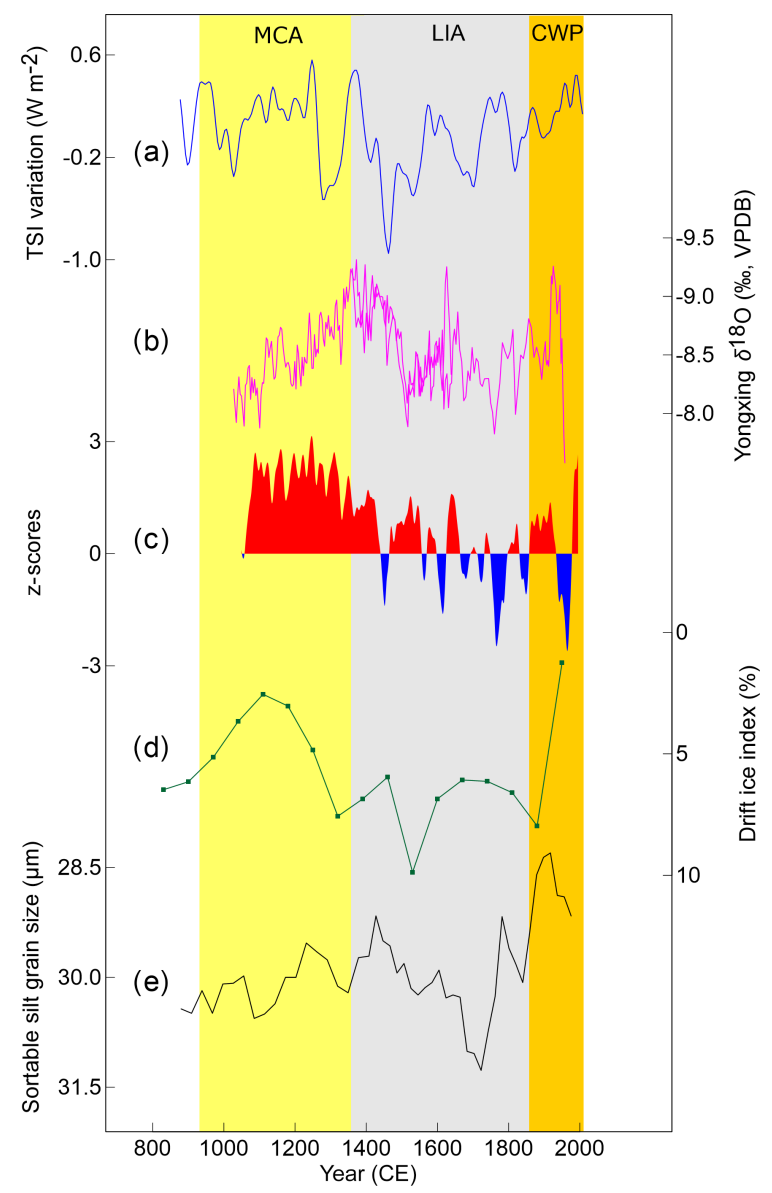

Figure 7. A comparison among Meiyu rain, solar activity, and North Atlantic climate. (a) Total solar irradiance (Steinhilber et al., 2009); (b) Yongxing Cave record (this study); (c) North Atlantic Oscillation index (Trouet et al., 2009); (d) North Atlantic drift ice index (Bond et al., 2001); (e) sortable silt grain size in the North Atlantic (Thornalley et al., 2018). Yellow, grey, and orange bands represent the MCA, LIA, and CWP, respectively.

weak AMOC during the LIA. These strong correlations indicate an influence of the NAO and AMOC on the EASM. During the MCA, positive NAO induces a warmer winter in Europe, which reduces snow accumulation over Eurasia and therefore allows for a farther penetration inland of the EASM the following summer (Overpeck et al., 1996). An analysis of instrumental data indicates that the winter NAO signal can be transmitted to East Asia through a wave train bridge and leads to a drier southern China but slightly wetter central China (Sung et al., 2006). On the other hand, Wu et al. (2009) have proposed that NAO-related spring sea surface temperature (SST) anomalies in the North Atlantic can produce anomalous anticyclonic circulations over the Okhotsk Sea, which help to enhance the subtropical monsoon front. A robust AMOC can intensify the EASM through the northward positioning of the ITCZ (Wang et al., 2017). During the LIA, a weaker NAO and AMOC would produce decreased
EASM in the reversed fashion. It has been proposed that conditions of the NAO are dynamically coupled to states of the AMOC (Trouet et al., 2009; Wanamaker et al., 2012). The strong (weak) NAO during the MCA (LIA) contributes to enhanced (weakened) AMOC by enhancing (weakening) the westerly (Trouet et al., 2009). A strong EASM, resulting from the strong NAO and AMOC, would shorten the Meiyu stage. Conversely, a weak EASM, resulting from the weak NAO and AMOC, would extend the Meiyu stage (Zhang et al., 2018c). On the other hand, solar activity is usually considered to be the root trigger of natural climate change. The Yongxing record is broadly similar to changes in solar irradiance (Steinhilber et al., 2009; see Fig. 7a). The decreased Meiyu rain is in parallel with greater solar activity during the MCA and the increased Meiyu rain with the less solar activity during the LIA. The solar forcing of the Meiyu rain variation, dependent on the EASM strength (Zhang et al., 2018c), can be determined by modulating the Asia-Pacific temperature contrast (Kutzbach et al., 2008), the AMOC intensity (Wang et al., 2005), and the ENSO condition (e.g., Asmerom et al., 2007; Zhao et al., 2016). However, the relative importance of these forcing pathways is unknown and, most importantly, the ENSO condition remains a matter of debate during the last millennium (e.g., Cobb et al., 2003; Yan et al., 2011a). As a counterpart to the MCA, the CWP is similarly marked by decreased Meiyu rain, strong AMOC, and high solar output (see Fig. 7). However, the relationship between the Meiyu rain and NAO condition is not significant during the CWP, with the decreased Meiyu rain failing to match the expected more positive NAO. Longer-term data from instrumental observations and historical proxies are needed to assess the linkage between the NAO condition and Meiyu rain during the CWP.

\section{Conclusions}

Based on new and recently published stalagmite records from the Yongxing Cave, central China, we reconstruct a continuous evolutional history of the Meiyu rain during the past millennium and link its variation to the Pacific and North Atlantic climates. The climatic characters in our record are generally antiphase with those in the Wanxiang and Huangye Cave records in northern China. The decreased (increased) Meiyu rain during the MCA (LIA) correlates with the warm (cold) surface temperature and enhanced (reduced) rainfall over the IPWP. Based on the strong correlation with the ENSO reconstruction, our records support an El Niño-like condition during the MCA and a La Niña-like condition during the LIA. In addition, our records show a potential link between the Meiyu rain and the North Atlantic climate. The decreased Meiyu rain coincides with a substantially positive $\mathrm{NAO}$ and robust AMOC during the MCA, while the increased Meiyu rain corresponds with a neutral to negative $\mathrm{NAO}$ and weak AMOC during the LIA. 
Data availability. Data in this study are available on request; please address requests to Fucai Duan (fcduan@foxmail.com).

Author contributions. FD, ZZ, and YW designed the study and wrote the paper. FD, ZZ, YW, and JC revised the paper. FD, QS, ZL, and $\mathrm{KZ}$ performed ${ }^{230} \mathrm{Th}$ dating and oxygen isotope measurements. FD and SC collected samples. All authors discussed the results and contributed to the paper.

Competing interests. The authors declare that they have no conflict of interest.

Acknowledgements. This work was supported by the Zhejiang Provincial Natural Science Foundation (no. LY19D020001) and the National Natural Science Foundation of China (nos. 41602181, 41572340, and 41572151). We are grateful to the editor, Dr. Qiuzhen Yin, and two anonymous reviewers for their helpful suggestions and comments that have greatly improved this paper.

Financial support. This research has been supported by the Zhejiang Provincial Natural Science Foundation (grant no. LY19D020001) and the National Natural Science Foundation of China (grant nos. 41602181, 41572340, and 41572151).

Review statement. This paper was edited by Qiuzhen Yin and reviewed by two anonymous referees.

\section{References}

An, Z., Clemens, S., Shen, J., Qiang, X., Jin, Z., Sun, Y., Prell, W., Luo, J., Wang, S., Xu, H., Cai, Y., Zhou, W., Liu, W., Shi, Z., Yan, L., Xiao, X., Chang, H., Wu, F., Ai, L., and Lu, F.: Glacial-interglacial Indian summer monsoon dynamics, Science, 333, 719-723, 2011.

Asmerom, Y., Polyak, V., Burns, S., and Rassmussen, J.: Solar forcing of Holocene climate: New insights from a speleothem record, southwestern United States, Geology, 35, 1-4, 2007.

Baker, A., Sodemann, H., Baldini, J., Breitenbach, S., Johnson, K., Hunen, J., and Zhang, P.: Seasonality of westerly moisture transport in the East Asian summer monsoon and its implications for interpreting precipitation $\delta^{18} \mathrm{O}$, J. Geophys. Res.-Atmos., 120, 5850-5862, 2015.

Bond, G., Kromer, B., Beer, J., Muscheler, R., Evans, M., Showers, W., Hoffmann, R., Lotti-Bond, R., Hajdas, I., and Bonani, G.: Persistent Solar Influence on North Atlantic Climate During the Holocene, Science, 294, 2130-2136, 2001.

Bradley, R. and Jonest, P.: "Little Ice Age" summer temperature variations: their nature and relevance to recent global warming trends, Holocene, 3, 367-376, 1993.

Bradley, R., Hughes, M., and Diaz, H.: Climate in Medieval Time, Science, 302, 404-405, 2003.

Carolin, S., Cobb, K., Adkins, J., Clark, B., Conroy, J., Lejau, S., Malang, J., and Tuen, A.: Varied response of western Pacific hy- drology to climate forcings over the last glacial period, Science, 340, 1564-1566, 2013.

Chen, J., Chen, F., Feng, S., Huang, W., Liu, J., and Zhou, A.: Hydroclimatic changes in China and surroundings during the Medieval Climate Anomaly and Little Ice Age: spatial patterns and possible mechanisms, Quaternary Sci. Rev., 107, 98-111, 2015.

Chen, T., Cobb, K., Roff, G., Zhao, J., Yang, H., Hu, M., and Zhao, K.: Coral-derived western Pacific tropical sea surface temperatures during the last millennium, Geophys. Res. Lett., 45, 3542 3549, 2018.

Cheng, H., Edwards, R. L., Broecker, W. S., Denton, G. H., Kong, X., Wang, Y., Zhang, R., and Wang, X.: Ice age terminations, Science, 326, 248-252, 2009.

Cheng, H., Edwards, R. L., Sinha, A., Spötl, C., Yi, L., Chen, S., Kelly, M., Kathayat, G., Wang, X., Li, X., Kong, X., Wang, Y., Ning, Y., and Zhang, H.: The Asian monsoon over the past 640,000 years and ice age terminations, Nature, 534, 640-646, 2016.

Cheng, H., Zhang, H., Zhao, J., Li, H., Ning, Y., and Kathayat, G.: Chinese stalagmite paleoclimate researches: A review and perspective, Sci. China Earth Sci., 62, 1489-1513, 2019.

Cheung, R., Yasuhara, M., Mamo, B., Katsuki, K., Seto, K., Takata, H., Yang, D., Nakanishi, T., Yamada, K., and Iwstani, H.: Decadal-to Centennial-Scale East Asian Summer Monsoon variability over the past millennium: An Oceanic Perspective, Geophys. Res. Lett., 45, 7711-7718, 2018.

Chu, G., Liu, J., Sun, Q., Lu, H., Gu, Z., Wang, W., and Liu, T.: The "Mediaeval Warm Period" drought recorded in Lake Huguangyan, tropical South China, Holocene, 12, 511-516, 2002.

Clemens, S., Holbourn, A., Kubota, Y., Lee, K., Liu, Z., Chen, G., Nelson, A., and Fox-Kemper, B.: Precession-band variance missing from East Asian monsoon runoff, Nat. Commun., 9, 3364, https://doi.org/10.1038/s41467-018-05814-0, 2018.

Clemens, S., Prell, W., and Sun, Y.: Orbital-scale timing and mechanisms driving Late Pleistocene Indo-Asian summer monsoons: Reinterpreting cave speleothem $\delta^{18} \mathrm{O}$, Paleoceanography, 25, PA4207, https://doi.org/10.1029/2010PA001926, 2010.

Cobb, K., Charles, C., Cheng, H., and Edwards, R.: El Nino/Southern Oscillation and tropical Pacific climate during the last millennium, Nature, 424, 271-276, 2003.

Deng, W., Liu, X., Chen, X., Wei, G., Zeng, T., Xie, L., and Zhao, J.: A comparison of the climates of the Medieval Climate Anomaly, Little Ice Age, and Current Warm Period reconstructed using coral records from the northern South China Sea, J. Geophys. Res.-Oceans., 122, 264-275, 2017.

Dorale, J. and Liu, Z.: Limitations of Hendy test criteria in judging the paleoclimate suitability of speleothems and the need for replication, J. Cave Karst Stud., 71, 73-80, 2009.

Ge, Q., Guo, X., Zheng, J., and Hao, Z.: Meiyu in the middle and lower reaches of the Yangtze River since 1736, Chinese Sci. Bull., 53, 107-114, 2008.

Griffiths, M., Kimbrough, A, Gagan, M., Drysdale, R., Cole, J., Johnson, K., Zhao, J., Cook, B., Hellstrom, J., and Hantoro, W.: Western Pacific hydroclimate linked to global climate variability over the past two millennia, Nat. Commun., 7, 11719, https://doi.org/10.1038/ncomms11719, 2016. 
Haug, G., Hughen, K., Sigman, D., Peterson, L., and Röhl, U.: Southward migration of the intertropical convergence zone through the Holocene, Science, 293, 1304-1308, 2001.

He, B., Zhang, S., and Cai, S.: Climatic changes recorded in peat from the Dajiu Lake basin in Shennongjia since the last 2600 years, Mar. Geol. Quat. Geol., 23, 109-115, 2003 (in Chinese with English abstract).

Hegerl, G., Crowley, T., Allen, M., Hyde, W., Pollack, H., Smerdon, J., and Zorita, E.: Detection of Human Influence on a New, Validated 1500-Year Temperature Reconstruction, J. Climate, 20, 650-666, 2007.

Hu, C., Henderson, G., Huang, J., Xie, S., Sun, Y., and Johnson, K.: Quantification of Holocene Asian monsoon rainfall from spatially separated cave records, Earth Planet Sc. Lett., 266, 221232, 2008.

Jiang, X., Wang, X., He, Y., Hu, H. M., Li, Z., Spötl, C., and Shen, C. C.: Precisely dated multidecadally resolved Asian summer monsoon dynamics 113.5-86.6 thousand years ago, Quaternary Sci. Rev., 143, 1-12, 2016.

Karami, M., Herold, N., Berger, A., Yin, Q., and Muri, H.: State of the tropical Pacific Ocean and its enhanced impact on precipitation over East Asia during marine isotopic stage 13, Clim. Dynam., 44, 807-825, 2015.

Kutzbach, J., Liu, X., Liu, Z., and Chen, G.: Simulation of the evolutionary response of global summer monsoons to orbital forcing over the past 280,000 years, Clim. Dynam., 2008, 30, 567-579, 2008.

Lamb, H.: Climate, History and the Modern World, London, Routledge, https://doi.org/10.4324/9780203433652, 2002.

Lamoureux, S., England, J., Sharp, M., and Bush, A.: A varve record of increased "Little Ice Age" rainfall associated with volcanic activity, Arctic Archipelago, Canada, Holocene, 11, 243249, 2001.

Mann, M., Zhang, Z., Hughes, M., Bradley, R., Miller, S., Rutherford, S., and Ni, F.: Proxy-Based Reconstructions of Hemispheric and Global Surface Temperature Variations over the Past Two Millennia, P. Natl. Acad. Sci. USA, 105, 13252-13257, 2008.

Mann, M., Zhang, Z., Rutherford, S., and Bradley, R., Hughes, M., Shindell, D., Ammann, C., Faluvegi, G., and Ni, F.: Global Signatures and Dynamical Origins of the Little Ice Age and Medieval Climate Anomaly, Science, 326, 1256-1260, 2009.

Moy, C., Seltzer, G., Rodbell, D., and Anderson, D.: Variability of El Niño/Southern Oscillation activity at millennial timescales during the Holocene epoch, Nature, 420, 162-165, 2002.

Oppo, D., Rosenthal, Y., and Linsley, B.: 2,000-year-long temperature and hydrology reconstructions from the Indo-Pacific warm pool, Nature, 460, 1113-1116, 2009.

Overpeck, J., Anderson, D., Trumbore, S., and Prell, W.: The southwest Indian Monsoon over the last 18000 years, Clim. Dynam., 12, 213-225, 1996.

PAGES 2k Consortium: Continental-scale temperature variability during the past two millennia, Nat. Geosci., 6, 339-346, 2013.

Paulsen, D., Li, H., and Ku, T.: Climate variability in central China over the last 1270 years revealed by high-resolution stalagmite records, Quaternary Sci. Rev., 22, 691-701, 2003.

Rustic, G., Koutavas, A., Marchitto, T., and Linsley, B.: Dynamical excitation of the tropical Pacific Ocean and ENSO variability by Little Ice Age cooling, Science, 350, 1537-1541, 2015.
Scholz, D. and Hoffmann, D.: StalAge-An algorithm designed for construction of speleothem age models, Quat. Geochronol., 6, 369-382, 2011.

Shao, Q., Pons-Branchu, E., Zhu, Q., Wang, W., Valladas, H., and Fontugne, M.: High precision U/Th dating of the rock paintings at Mt. Huashan, Guangxi, southern China, Quaternary Res., 88, 1-13, 2017.

Sigl, M., McConnell, J., Toohey, M., Curran, M., Das, S., Edwards, R., Isaksson, E., Kawamura, K., Kipfstuhl, S., Krüger, K., Layman, L., Maselli, O., Motizuki, Y., Motoyama, H., Pasteris, D., and Sandeveri, M.: Insights from Antarctica on volcanic forcing during the Common Era, Nat. Clim. Change, 4, 693-697, 2014.

Steinhilber, F., Beer, J., and Frohlich, C.: Total solar irradiance during the Holocene, Geophys. Res. Lett., 36, L19704, https://doi.org/10.1029/2009GL040142, 2009.

Sung, M., Kwon, W., Baek, H., Boo, K., Lim, G., and Kug, J.: A possible impact of the North Atlantic Oscillation on the east Asian summer monsoon precipitation, Geophys. Res. Lett., 33, L21713, https://doi.org/10.1029/2006GL027253, 2006.

Tan, L., Cai, Y., Cheng, H., An, Z., and Edwards, R.: Summer monsoon precipitation variations in central China over the past 750 years derived from a high-resolution absolute-dated stalagmite, Palaeogeogr. Palaeocl., 280, 432-439, 2009.

Tan, L., Cai, Y., An, Z., Yi, L., Zhang, H., and Qin, S.: Climate patterns in north central China during the last 1800 $\mathrm{yr}$ and their possible driving force, Clim. Past, 7, 685-692, https://doi.org/10.5194/cp-7-685-2011, 2011a.

Tan, L., Cai, Y., An, Z., Edwards, R., Cheng, H., Shen, C., and Zhang, H.: Centennial-to decadal-scale monsoon precipitation variability in the semi-humid region, northern China during the last 1860 years: Records from stalagmites in Huangye Cave, Holocene, 21, 287-296, 2011 b.

Tan, L., Cai, Y., An, Z., Cheng, H., Shen, C., Breitenbach, S., Gao, Y., Edwards, R., Zhang, H., and Du, Y.: A Chinese cave links climate change, social impacts, and human adaptation over the last 500 years, Sci. Rep., 5, 12284, https://doi.org/10.1038/srep12284, 2015.

Tan, L., Cai, Y., Cheng, H., Edwards, L., Lan J., Zhang, H., Li, D., Ma, L., Zhao, P., and Gao, Y.: High resolution monsoon precipitation changes on southeastern Tibetan Plateau over the past 2300 years, Quaternary Sci. Rev., 195, 122-132, 2018.

Tan, L., Shen, C., Löwemark, L., Chawchai, S., Edwards, R., Cai, Y., Breitenbach, S., Cheng, H., Chou, Y., Duerrast, H., Partin, J., Cai, W., Chabangborn, A., Gao, Y., Kwiecien, O., Wu, C., Shi, Z., Hsu, H., and Wohlfarth, B.: Rainfall variations in central IndoPacific over the past 2700 y, P. Natl. Acad. Sci. USA, 1720117206, 10.1073/pnas.1903167116, 2019.

Tan, M.: Circulation effect: response of precipitation $\delta^{18} \mathrm{O}$ to the ENSO cycle in monsoon regions of China, Clim. Dynam., 42, 1067-1077, 2014.

Tan, M.: Circulation background of climate patterns in the past millennium: Uncertainty analysis and re-reconstruction of ENSO-like state, Sci. China Earth Sci., 59, 1255-1241, https://doi.org/10.1007/s11430-015-5256-6, 2016.

Tan, M., Liu, D., Hou, J., Qin, X., Zhang, H., and Li, T.: Cyclic rapid warming on centennial-scale revealed by a 2650 -year stalagmite record of warm season temperature, Geophys. Res. Lett., 30, 1617, https://doi.org/10.1029/2003GL017352, 2003. 
Thornalley, D., Oppo, D., Ortega, P., Robson, J., Brierley, C., Davis, R., Hall, I., Moffa-Sanchez, P., Rose, N., Spooner, P., Yashayaev, I., and Keigwin, L.: Anomalously weak Labrador Sea convection and Atlantic overturning during the past 150 years, Nature, 556, 227-230, 2018.

Trouet, V., Esper, J., Graham, N., Baker, A., Scourse, J., and Frank, D.: Persistent Positive North Atlantic Oscillation Mode Dominated the Medieval Climate Anomaly, Science, 324, 78-80, 2009.

Wanamaker Jr., A., Butler, P., Scourse, J., Heinemeier, J., Eiríksson, J., Knudsen, K., and Richardson, C.: Surface changes in the North Atlantic meridional overturning circulation during the last millennium, Nat. Commun., 3, 899, https://doi.org/10.1038/ncomms1901, 2012.

Wang, B., Liu, J., Kim, H., Webster, P., Yim, S., and Xiang, B.: Northern Hemisphere summer monsoon intensified by mega-El Nino/southern oscillation and Atlantic multidecadal oscillation, P. Natl. Acad. Sci. USA., 110, 5347-5352, 2013.

Wang, X., Edwards, R., Auler, A., Cheng, H., Kong, X., Wang, Y., Cruz, F., Dorale, J., and Chiang, H.: Hydroclimate changes across the Amazon lowlands over the past 45,000 years, Nature, 541, 204-207, 2017.

Wang, Y., Cheng, H., Edwards, R., An, Z., Wu, J., Shen, C., and Dorale, J.: A high-resolution absolute-dated late Pleistocene monsoon record from Hulu Cave, China, Science, 294, 2345-2348, 2001a.

Wang, Y., Wang, B., and Oh, J.: Impact of the preceding El Niño on the East Asian summer atmosphere circulation, J. Meteorol. Soc. Jpn., 79, 575-588, 2001b.

Wang, Y., Cheng, H., Edwards, R., He, Y., Kong, X., An, Z., Wu, J., Kelly, M., Dykoski, C., and Li, X.: The Holocene Asian monsoon: Links to solar changes and North Atlantic climate, Science, 308, 854-857, 2005.

Wu, Z., Wang, B., Li, J., and Jin, F.: An empirical seasonal prediction model of the east Asian summer monsoon using ENSO and NAO, J. Geophys. Res., 114, D181120, https://doi.org/10.1029/2009JD011733, 2009.

Xu, H., Lan, J., Sheng, E., Liu, B., Yu, K., Ye, Y., Shi, Z., Cheng, P., Wang, X., Zhou, X., and Yeager, K.: Hydroclimatic contrasts over Asian monsoon areas and linkages to tropical Pacific SSTs, Sci. Rep., 6, 33177, https://doi.org/10.1038/srep33177, 2016.

Yan, H., Sun, L., Oppo, D., Wang, Y., Liu, Z., Xie, Z., Liu, X., and Cheng, W.: South China Sea hydrological changes and Pacific Walker Circulation variations over the last millennium, Nat. Commun., 2, https://doi.org/10.1038/ncomms1297, 2011a.

Yan, H., Sun, L., Wang, Y., Huang, W., Qiu, S., and Yang, C.: A record of the Southern Oscillation Index for the past 2,000 years from precipitation proxies, Nat. Geosci., 4, 611-614, 2011b.

Yan, H., Wei, W., Soon, W., An, Z., Zhou, W., Liu, Z., Wang, Y., and Carter, R.: Dynamics of the intertropical convergence zone over the western Pacific during the Little Ice Age, Nat. Geosci., 8, https://doi.org/10.1038/ngeo2375, 2015.

Yu, R. and Zhou, T.: Seasonality and Three-Dimensional Structure of Interdecadal Change in the East Asian Monsoon, J. Climate, 20, 5344-5355, 2007.
Yuan, D., Cheng, H., Edwards, R., Dykoski, C., Kelly, M., Zhang, M., Qing, J., Lin, Y., Wang, Y., Wu, J., Dorale, J., An, Z., and Cai, Y.: Timing, durationand transitions of the last interglacial Asian monsoon, Science, 304, 575-578, 2004.

Zhang, H., Cheng, H., Spötl, C., Cai, Y., Sinha, A., Tan, L., Yi, L., Yan, H., Kathayat, G., Ning, Y., Li, X., Zhang, F., Zhao, J., and Edwards, R.: A 200-year annually laminated stalagmite record of precipitation seasonality in southeastern China and its linages to ENSO and PDO, Sci. Rep, 8, 12344, https://doi.org/10.1038/s41598-018-30112-6, 2018a.

Zhang, H., Cheng, H., Cai, Y., Spötl, C., Kathayat, G., Sinha, A., Edwards, R. L., and Tan, L.: Hydroclimatic variations in southeastern China during the $4.2 \mathrm{ka}$ event reflected by stalagmite records, Clim. Past, 14, 1805-1817, https://doi.org/10.5194/cp14-1805-2018, 2018b.

Zhang, H., Griffiths, M., Chiang, J., Kong, W., Wu, S., Atwood, A., Huang, J., Cheng, H., Ning, Y., and Xie, S.: East Asian hydroclimate modulated by the position of the westerlies during Termination I, Science, 362, 580-583, 2018c.

Zhang, H., Brahim, Y., Li, H., Zhao, J., Kathayat, G., Tian, Y., Baker, J., Wang, J., Zhang, F., Ning, Y., Edwards, R., and Cheng, H.: The Asian Summer Monsoon: Teleconnections and Forcing Mechanisms-A Review from Chinese Speleothem $\delta^{18} \mathrm{O}$ Records, Quaternary, 2, 26, https://doi.org/10.3390/quat2030026, 2019.

Zhang, P., Cheng, H., Edwards, R., Chen, F., Wang, Y., Yang, X., Liu, J., Tan, M., Wang, X., Liu, J., An, C., Dai, Z., Zhou, J., Zhang, D., Jia, J., Jin, L., and Johnson, K.: A test of climate, sun, and culture relationships from an 1810-year Chinese cave record, Science, 322, 940-942, 2008.

Zhang, W., Chen, S., Wang, Y., Zhao, K., Shao, Q., Wang, T., and Zhu, L.: Rapid changes in the East Asian summer monsoon: stalagmite records in Hubei, China, Quaternary Sci., 39, 765-774, 2019 (in Chinese with English abstract).

Zhao, K., Wang, Y., Edwards, R., Cheng, H., and Liu, D.: Highresolution stalagmite $\delta^{18} \mathrm{O}$ records of Asian monsoon changes in central and southern China spanning the MIS3/2 transition, Earth Planet Sc. Lett., 298, 191-198, 2010.

Zhao, K., Wang, Y., Edwards, R., Cheng, H., Liu, D., and Kong, $\mathrm{X}$.: A high-resolved record of the Asian Summer Monsoon from Dongge Cave, China for the past 1200 years, Quaternary Sci. Rev., 122, 250-257, 2015.

Zhao, K., Wang, Y., Edwards, R., Cheng, H., Liu, D., Kong, X., and Ning, Y.: Contribution of ENSO variability to the East Asian summer monsoon in the late Holocene, Palaeogeogr. Palaeocl., 449, 510-519, 2016.

Zhou, T., Gong, D., Li, J., and Li, B.: Detecting and understanding the multi-decadal variability of the East Asian Summer Monsoon-Recent progress and state of affairs, Meteorol. Z., 13, 455-467, 2009. 